\title{
₹USGS
}

\section{Selected Geologic Maps of the Kodiak Batholith and Other Paleocene Intrusive Rocks, Kodiak Island, Alaska}

By David W. Farris and Peter J. Haeussler

Pamphlet to accompany

Scientific Investigations Map 3441 


\title{
U.S. Department of the Interior \\ DAVID BERNHARDT, Secretary
}

\author{
U.S. Geological Survey \\ James F. Reilly II, Director
}

U.S. Geological Survey, Reston, Virginia: 2020

For more information on the USGS —-the Federal source for science about the Earth, its natural and living resources, natural hazards, and the environment-visit https://www.usgs.gov or call 1-888-ASK-USGS.

For an overview of USGS information products, including maps, imagery, and publications,

visit https://store.usgs.gov.

Any use of trade, firm, or product names is for descriptive purposes only and does not imply endorsement by the U.S. Government.

Although this information product, for the most part, is in the public domain, it also may contain copyrighted materials as noted in the text. Permission to reproduce copyrighted items must be secured from the copyright owner.

Suggested citation:

Farris, D.W., and Haeussler, P.J., 2020, Selected geologic maps of the Kodiak batholith and other Paleocene intrusive rocks, Kodiak Island, Alaska: U.S. Geological Survey Scientific Investigations Map 3441, pamphlet 10 p., scale 1:50,000, https://doi.org/10.3133/sim3441.

ISSN 2329-132X (online) 


\section{Contents}

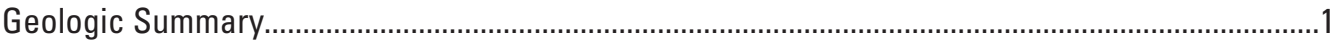

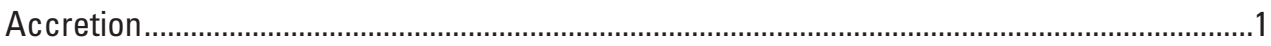

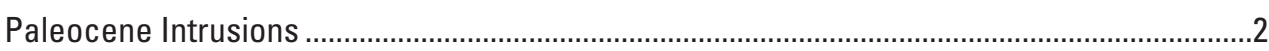

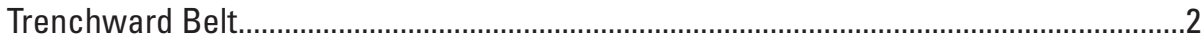

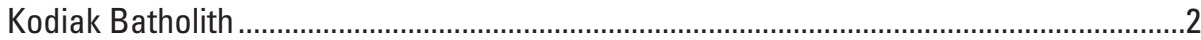

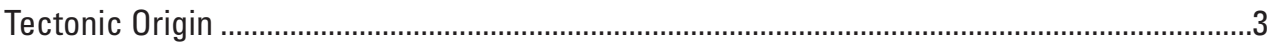

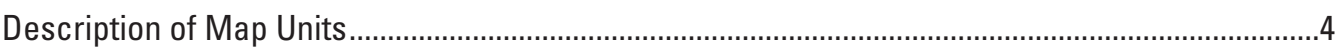

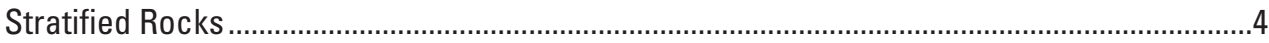

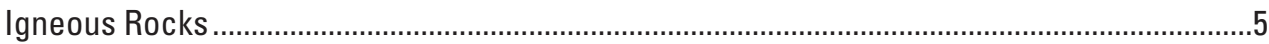

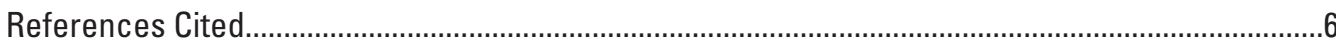

\section{Figures}

1. Map of Kodiak Island showing the Kodiak batholith, other Paleocene intrusive rocks, regional structures, location of gravity transect, geochronology sample locations, and map locations....................................... map sheet

2. Gravity transect and model across the Kodiak batholith.................................... map sheet

\section{Tables}

1. Published geochronology data for samples from Kodiak Island, Alaska.

\section{Maps}

A. Kodiak batholith near Terror Lake...................................................................map sheet

B. Whale Passage pluton .......................................................................................map sheet

C. Anton Larsen Bay pluton ............................................................................map sheet

D. Kodiak batholith at Three Saints Bay ..........................................................map sheet

E. Sitkalidak pluton at Sikalidak Strait................................................................map sheet

F. Trenchward belt intrusive rocks near Pasagshak Bay........................................map sheet 


\title{
Selected Geologic Maps of the Kodiak Batholith and Other Paleocene Intrusive Rocks, Kodiak Island, Alaska
}

\author{
David W. Farris ${ }^{1}$ and Peter J. Haeussler ${ }^{2}$
}

\section{Geologic Summary}

\section{Accretion}

Kodiak Island is dominantly composed of a large accretionary complex that has units spanning approximately the past 200 million years (see fig. 1, map sheet; Moore and others, 1983; Plafker and others, 1989, 1994; Roeske and others, 1989). The rate at which material was accreted was not constant, but it greatly fluctuated over that interval. Major episodes of accretion occurred in the early Jurassic (approximately $180 \mathrm{Ma}$, glaucophane in the Raspberry Schist of Roeske and others, 1989, on Afognak Island), the Late Cretaceous (Kodiak Formation), the Paleocene (Ghost Rocks Formation), and the Oligocene (underplating event, Clendenen and others, 2003). However, this study focused on the Late Cretaceous and younger units that lie to the southeast of the three strands of the Border Ranges Fault system (namely, the Shuyak Thrust, the Border Ranges Fault, and the Uganik Thrust) as described by Roeske and others (1989).

The two most volumetrically significant accretionary events occurred in the Late Cretaceous and Paleocene, which resulted in the deposition and subsequent accretion of the Kodiak and Ghost Rocks Formations. The Late Cretaceous accretionary episode resulted in a belt of argillite and graywacke turbidite deposits that are 60 to $70 \mathrm{~km}$ wide and almost 2,000 $\mathrm{km}$ in length. Nilsen and Moore (1979) estimated the depositional thickness of the Kodiak Formation at approximately $5,000 \mathrm{~m}$; however, owing to homogeneity and lack of distinctive marker beds, that estimate is uncertain. The processes of accretion and underplating structurally repeated the units many times (Nilsen and Moore, 1979; Sample and Moore, 1987), and these processes caused Kodiak Formation bedding planes to have a highly consistent strike of approximately $225^{\circ}$. Correlative units along strike include the Shumagin Formation (on Shumagin and Sanak Islands in the Aleutian Islands), the Valdez Group (on the Kenai Peninsula and in the Chugach Mountains to the northeast), and the Sitka Graywacke (in southeastern Alaska). The age of the Kodiak Formation is derived from the presence of early Maastrichtian Inoceramus fossils (Jones and Clark, 1973;

\footnotetext{
${ }^{1}$ East Carolina University

${ }^{2}$ U.S. Geological Survey
}

Sample and Reid, 2003). The Kodiak Formation and similar units are thought to be the repository of detritus from a large Late Cretaceous orogenic event (Sample and Reid, 2003). In addition, detrital zircon observations from Garver and Davidson (2015) and Mahjoor (2011) also provide Late Cretaceous minimum depositional ages for the Kodiak Formation. The granitic rocks of the Kodiak batholith and its satellite plutons (maps A-F, map sheet) intruded into the Kodiak Formation during the Paleocene.

The younger accretionary episode resulted in deposition and offscraping of the Paleocene Ghost Rocks Formation. Like the Kodiak Formation, it is mainly composed of graywacke and argillite, but it is more thickly bedded, contains more graywacke, is lighter in color, is less structurally coherent, and contains significant sections of mélange (trenchward belt intrusive rocks near Pasagshak Bay, map F). Fisher and Byrne (1987) argued that the paleosubduction-zone megathrust cut through the southeast edge of the Ghost Rocks Formation on Kodiak Island, which would correspond to the Ghost Rocks Formation mélange shown near Pasagshak Bay on map F. Subsequent work of Rowe and others (2005) and Meneghini and others (2010) have added additional support that such kilometer-scale mélange zones are preserved subduction-zone megathrusts. Dikes of gabbro, basalt, and andesite, as well as small granitic and gabbroic plutons, intruded the Ghost Rocks Formation (see fig. 1 and maps D, E, and F). We informally refer to these igneous rocks as the trenchward belt.

Previous workers included interbedded basalt and andesite as part of the Ghost Rocks Formation (Nilsen and Moore, 1979; Moore and others, 1983; Plumley and others, 1983). However, in the Pasagshak Bay area, we observed that most of the basalt and andesite are dikes that intrude the Ghost Rocks Formation. Many of the dikes are parallel to the mélange fabric, but they are intact bodies and, therefore, must have intruded after fabric formation. Some of the gabbro bodies grade into basalt dikes, and some of the basalt dikes grade into pillows. Consequently, we interpret that most of the igneous rocks at a given point along strike intruded at approximately the same time and that, at least on the northeastern side of Kodiak Island, they intruded after the Ghost Rocks Formation was deposited.

However, several observations suggest that the deposition and accretion of the Ghost Rocks Formation and the 
intrusion of the trenchward belt rocks must have been temporally linked. Pillow basalt forms on the ocean floor, and certain pillow-basalt piles are topped by bedded sedimentary rocks of the Ghost Rocks Formation. Therefore, some deposition of Ghost Rocks Formation sediments occurred after the igneous rocks formed, but, because most of the igneous rocks in the Pasagshak Bay area are intrusive, the magmatic event must have occurred very near the end of the depositional period of the Ghost Rocks Formation. We obtained an ${ }^{40} \mathrm{Ar} /{ }^{39} \mathrm{Ar}$ wholerock date of $60.2 \pm 0.9 \mathrm{Ma}$ (table 1; fig. 1) on one of the basalt dikes at Pasagshak Bay (Farris, 2010). This age is younger than the K-Ar biotite and Rb-Sr ages of 63 to $62 \mathrm{Ma}$ obtained on trenchward-belt plutons on the southwest end of Kodiak Island near Japanese Bay (Moore and others 1983). Also, Moore and others (1983) and Nilsen and Moore (1979) report that most of the basalt and andesite in this part of the island are interbedded with graywacke and argillite from the Ghost Rocks Formation. One interpretation is that trenchward-belt igneous rocks on the southwest side of the island erupted while the Ghost Rocks Formation was being deposited, and therefore they have a greater extrusive component. On the northeast side of Kodiak Island at Pasagshak Bay, most of the Ghost Rocks Formation had already been deposited by $60 \mathrm{Ma}$, so the trenchward-belt rocks are dominantly intrusive.

\section{Paleocene Intrusions}

\section{Trenchward Belt}

The trenchward-belt igneous rocks are composed of elongate granite bodies, basaltic dikes, and small gabbroic plutons that lie along or to the southeast of the trend of the Kalsin Bay Fault (fig. 1), commonly called the "Contact Fault" in southern Alaska literature. A whole-rock ${ }^{40} \mathrm{Ar} /{ }^{39} \mathrm{Ar}$ age of the Pasagshak basalts (unit Tdp, 60.2 $\pm 0.9 \mathrm{Ma}$ ) suggests that they are slightly older than the Kodiak batholith (Farris, 2010). The trenchwardbelt intrusions were emplaced at shallow crustal levels, which is evidenced by dikes that grade into pillow basalts. However, intrusions become coarser grained and generally appear to deepen in emplacement level to the northwest toward the Kalsin Bay Fault. Conversely, near Pasagshak Point (map F), dikes (unit Tcg) that intruded the Ghost Rocks Formation are in close association with pillow basalts that are interbedded with sediment; these relations indicate emplacement at the surface. The basaltic dikes crosscut Ghost Rocks Formation bedding and cleavage, have margins that are chilled and almost glassy, and baked the adjacent host rock. Small fragments of host rock are occasionally found in the dikes and pillows. Our interpretation is that the basaltic rocks intruded the Ghost Rocks Formation and that they are not blocks caught up in a mélange.

In the Pasagshak Bay area (map F), the intrusive rocks (unit Tcg) are 10- to 50-m-wide porphyritic dikes (plagioclase phenocrysts) on the northwest side of the bay and are pillow basalts and 10- to 300-cm-wide, fine-grained dikes southeast of Pasagshak Point. The wider porphyritic dikes fine upward in grain size. At the base of some of the larger dikes on the northwest side of Pasagshak Bay, the gabbro has a cumulate texture with large (1- to 2-cm-high) labradorite $(A n=50-60)$ plagioclase crystals. The interstices of the large plagioclase grains are filled with smaller intergrown plagioclase $(\mathrm{An}=30)$ and clinopyroxene. At higher structural levels within the dikes, larger plagioclase phenocrysts are not found, and textures are more equigranular. At the top of some dikes, balloon-like structures filled with fine-grained basalt intrude into the overlying Ghost Rocks Formation. We suggest that the larger dikes were initially formed by the injection of phenocryst-rich magma. Subsequently the large plagioclase phenocrysts settled to the bottom to form cumulates and the remaining liquid crystallized.

On Sitkalidak Island (map E), the gabbroic rocks are slivers of material exhumed in the hanging wall of the Kalsin Bay Fault. They are composed of coarse-grained (centimeter-scale) clinopyroxene and plagioclase. Individual gabbroic dikes are not present as they are at Pasagshak Bay (map F); instead, the exposures appear to be fragments of originally more equant plutonic bodies.

Granitic plutons are found in close proximity to gabbro at Pasagshak Bay and on Sitkalidak Island. In the large Pasagshak pluton (map F), there are 100-m-scale gabbroic pods (unit Tcg) within the granodiorite, near the center of the intrusion. One of the distinguishing features of these granitic plutons is the presence of partially reabsorbed mafic phenocrysts. These are generally clinopyroxene, but one sample from Sitkalidak Island (map E) contains altered olivine phenocrysts. The olivine and clinopyroxene phenocrysts are strongly embayed and are often surrounded by quartz and potassium feldspar. Larger white feldspar phenocrysts also tend to be surrounded by fine-grained, intergrown, almost-granophyric quartz and potassium feldspar. The Shaft Peak pluton (map F) contains zones that are characterized by concentrations of stoped blocks that exceed 50 percent by volume. The stoped blocks are fragments of argillite and graywacke from the Ghost Rocks Formation. The combined observations of olivine and clinopyroxene phenocrysts, larger gabbroic pods, and the large volumes of stoped blocks suggest that the trenchward-belt granites are a product of local sediment assimilation and melting caused by the intrusion of mafic magma. However, the granitic systems froze before significant volumes of host rock could be completely assimilated.

The mafic magmas were emplaced primarily as dikes, and the granitic bodies were emplaced by the stoping of host rock. Both the mafic and felsic intrusions in the trenchward belt were emplaced by fracture- and (or) crack-dominated processes. We suggest that this is due to the shallow depth of emplacement, the relatively small size of individual intrusions, and the higher mafic content. These factors act to decrease viscosity and increase temperature, thermal gradients, and cooling rates, all of which increase the likelihood of crack-based emplacement mechanisms.

\section{Kodiak Batholith}

A continuously exposed body of granitic rocks composed of multiple plutons extends for over $110 \mathrm{~km}$ along the axis of Kodiak Island and ranges in width from 2 to $10 \mathrm{~km}$. Six U/Pb dates along its axis range from 59.2 $\pm 0.2 \mathrm{Ma}$ in the southwest to $58.4 \pm 0.2 \mathrm{Ma}$ near its northwest tip (Farris and others, 2006). 
The batholith is composed primarily of granite and granodiorite, but it also includes tonalite and minor diorite. The intrusive rocks are texturally homogeneous around the margins and near the northeastern tip (map A). The interior of the batholith contains elliptical zones having high percentages of partially assimilated host-rock inclusions (map A).

Using the amount of included residual host rock, we divided the Kodiak batholith granitic rocks into high-, medium-, and low-inclusion units. Preliminary oxygen-isotope and chemical data indicate that these units correspond to the total percentage of host-rock material in the granitic rocks (Tangalos and others, 2003; Farris, 2010). The low-inclusion unit contains almost no macroscopic inclusions of host-rock material. The medium- and high-inclusion units respectively contain 5 to 10 and 10 to 50 percent partially assimilated host-rock inclusions, which consist of numerous host-rock xenoliths, biotite aggregates, pure quartz clots, and large $\mathrm{Al}_{2} \mathrm{SiO}_{5}$ xenocrysts. Most of the xenocrysts we observed were sillimanite, but kyanite, andalusite, and garnet are also present and have been observed in other Sanak-Baranof belt plutons (Moore and others, 1983; Kusky and others, 2003). High-inclusion units appear as if they formed from a slurry of granitic magma and partially assimilated host rock.

The metamorphic mineral assemblage present in the host-rock fragments of the medium- and high-inclusion units is higher grade than that found in the contact aureole. This observation suggests that the host-rock slurry did not come from the adjacent margin, but it was instead transported vertically to its present position (Kusky and others, 2003; Farris and others, 2003, 2006). A gravity transect across the batholith (figs. 1 and 2) indicates that rocks with the same density as the high-inclusion unit extend downwards for at least 5 to $10 \mathrm{~km}$ (Farris and others, 2003, 2006). This is approximately the same distance of vertical transport suggested by the metamorphic grade of the high-assimilation-unit xenoliths.

The dominant fabric in the Kodiak batholith is a magmatic foliation of weak to moderate intensity. The foliation is defined by the alignment of feldspars and biotite of magmatic origin. It is most intense in high-assimilation zones located in the center of the batholith, which have the highest concentrations of biotite. The magmatic fabric is oriented parallel to the long axis of the batholith and is steeply dipping. It is also parallel to the dominant bedding and cleavage orientation in the Kodiak Formation. In general, the magmatic fabric is undeflected by proximity to the pluton margin, and this remains true even where the pluton margin and magmatic fabric intersect at high angles. That relation is illustrated well in the Anton Larsen Bay pluton (map C) and along Kizhuyak Bay (map A). Foliations in xenoliths and the long axis of isolated xenocrysts also tend to be aligned with the magmatic fabric. However, there are examples (near Terror Lake, map A) in which the magmatic fabric in the granite has been deflected around a host-rock xenolith. We interpret the Kodiak batholith magmatic foliation to have formed late in its crystallization history and to be the result of the regional tectonic strain field at the time it passed through its solidus.

The Kodiak batholith thermal aureole contains a peak assemblage of garnet, cordierite, and biotite that indicates metamorphic conditions of approximately $650^{\circ} \mathrm{C}$ and 2-3 kbar. Cordierite is by far the most common metamorphic mineral in the aureole and we have mapped its first appearance as the boundary of the high-temperature aureole (maps A-D). The cordierite aureole width is positively correlated with the width of the batholith, and it ranges from 0.1 to $2-3 \mathrm{~km}$ wide. Bulges or extensions of the cordierite isograd with respect to the pluton margin infer buried parts of the batholith. Biotite is the first metamorphic mineral in the aureole to appear, but its first appearance was not mapped. However, we tentatively estimate the location of the biotite isograd as being more than $3-5 \mathrm{~km}$ from the batholith margin. The thermal aureole is wider than the structural aureole.

Deformation in the structural aureole is somewhat heterogeneous, but a common pattern can be distinguished that provides insight into the emplacement mechanisms of the batholith. Near the batholith margin, the aureole has undergone approximately 50 percent margin-parallel shortening and has had as much as 80 percent vertical extension (Farris and others, 2006). Strain markers are not plentiful, but the vertical extension values were derived from measuring quartz veins that had been folded and extended. Another useful marker for the characterization of the aureole deformation is Kodiak Formation bedding planes, which have a consistent orientation across Kodiak Island. The bedding planes are deflected towards the pluton margin on both the northwest and southeast sides of the batholith (map A, near Kizhuyak Bay, and map C). Such deformation is particularly evident in the north and south ends of the batholith and satellite plutons. Also, bedding tends to be folded near the pluton contact and forms rim synclines and anticlines (see cross sections $A-A^{\prime}$ and $B-B^{\prime}$, map A). All of these strain markers are consistent with downward flow of the aureole as the batholith ascended upwards (Farris and others, 2003, 2006).

In addition to the ductile structures, such as folds and boudins, stoped blocks and margin-parallel granitic dikes are present near the pluton contact. The effect of such brittle features was to transfer host rock from the pluton margin into the magma chamber itself. Host-rock blocks near the margin are qualitatively different from those found in the high-inclusion zones in the center of the batholith. Those near the margin are clearly from the adjacent Kodiak Formation and do not differ substantially from rocks in the inner aureole in terms of metamorphic grade and preservation of sedimentary structures. In comparison, host-rock material in the high- and mediuminclusion zones has undergone substantial recrystallization and porphyroblast growth and has had an extended magmatic transport history.

\section{Tectonic Origin}

The Kodiak batholith and the trenchward belt are both part of the forearc Sanak-Baranof plutonic belt, which extends for 2,100 km along the southern Alaskan margin. SanakBaranof-belt plutons intruded into what was, at the time, an active accretionary complex and decrease in age from $61 \mathrm{Ma}$ in the west to $51 \mathrm{Ma}$ in southeastern Alaska. The chemistry and isotopes of these intrusions can be explained by some mixture 
of sedimentary anatectic melts and mid-ocean-ridge basalt (Hill and others, 1981; Barker and others, 1992; Harris and others, 1996; Sisson and others, 2003; Ayuso and others, 2009; Farris, 2010). Marshak and Karig (1977) first proposed that the Sanak-Baranof belt could have formed by the subduction of an oceanic spreading ridge, and that concept has been supported by many subsequent workers (Hill and others, 1981; Moore and others, 1983; Bradley and others, 1993, 1998, 2003; Haeussler and others, 1995, 2003). One exception is Hudson (1994), who argued that the forearc plutons formed as a crustal melting event resulting from the subduction of hot, young oceanic crust-not from the spreading ridge itself. Overall, the mapping and the geochronology of the Kodiak batholith are compatible with the concept that it formed as a result of a migrating trench-ridgetrench triple junction. We interpret the individual plutons of the Kodiak batholith to track the location of the resultant slab window between 59 and $58 \mathrm{Ma}$ (Farris and others, 2003, 2006; Farris, 2010).

\section{DESCRIPTION OF MAP UNITS}

[Pluton maps are labeled with letters (map A). At the end of each unit description, letters in parentheses show which maps include the unit]

\section{STRATIFIED ROCKS}

Qu Undivided surficial deposits (Quaternary) — Unconsolidated sediments dominantly composed of silt, sand, gravel, and glacial till. Located either in thickly sedimented valley bottoms or as beach deposits and coastal alluvial fans. (Maps A-F)

Tnc Narrow Cape Formation (Miocene) - Tan, immature, poorly cemented shallow-marine siltstones, sandstones, and conglomerates that contain abundant molluscan fossils and Kodiak batholith granitic cobbles (Nilsen and Moore, 1979). The unit is approximately $700 \mathrm{~m}$ thick and unconformably lies above the Ghost Rocks and Sitkalidak Formations. The bottom of the unit contains a coarse-grained basal conglomerate and breccia with clasts as much as $40 \mathrm{~cm}$ across that are derived from the underlying Ghost Rocks Formation. Above the basal rocks, coarser grained conglomeratic beds are irregular and are $<1 \mathrm{~m}$ thick, whereas the finer grained sandstone and siltstone are more common. Also characteristic are 10- to 100-cm spherical sandstone concretions that often weather out of homogeneous fine-grained sandstone layers. The Miocene designation is based on an assemblage of molluscan fossils (Allison, 1976; Nilsen and Moore, 1979). (Map F)

Tsf Sitkalidak Formation (Oligocene and Eocene) - Dark-gray to black argillite and graywacke turbidites. Beds are very planar, and are typically 10 to $50 \mathrm{~cm}$ thick. Graywacke beds are thicker (as much as 1 to $3 \mathrm{~m}$ ) than argillite-rich layers and stand out in coastal exposures. Thicker graywacke beds often contain fragments of argillite rip-up clasts. Nilsen and Moore (1979) identified several channelized beds and measured a mean paleocurrent sediment-transport direction of $171 \pm 26^{\circ}$. The Sitkalidak Formation age is from Nilsen and Moore (1979). (Map F)

Ghost Rocks Formation (Paleocene) - The Paleocene age of the Ghost Rocks Formation is based on the presence of Globigerina pseudobulloides, Planorotolites sp., and Subbotina triangularis or S. triloculinoides planktonic foraminifers found in the limestone layers (Nilsen and Moore, 1979; Moore and others, 1983). In addition, the Ghost Rocks Formation is intruded by basaltic dikes and small granitic and gabbroic plutons, which range in age from 63 to $60 \mathrm{Ma}$ (Moore and others, 1983; Farris and others, 2005; Farris, 2010)

Tgrm Mélange-Mélange zone at the southern edge of the Ghost Rocks Formation (Moore and others, 1983; Fisher and Byrne, 1987). The rocks range from intensely folded and faulted beds of sandstone and shale to coherent sedimentary beds that are found only as isolated phacoidal structures surrounded by shale-dominated mélange. Rootless fold hinges and isoclinal folds are common throughout the mélange. Small faults are prevalent on a scale of tens of meters and truncate many folds. The intensity of bedding disruption and deformation increases to the southeast, and to the northwest the contact with the coherent strata (Tgr) of the Ghost Rocks Formation is gradational over several hundred meters. (Map F)

Tgr Coherent strata-Light-gray, highly deformed sandstone and shale. Graywacke beds tend to be coherent, weather to a rounded appearance, and are characterized by open short-period folds. Soft-sediment deformation is prevalent throughout. Shale-rich layers are not as common as sandstone layers, but they are typically more deformed and sometimes have a mélange texture. Bedding is typically 10 to $20 \mathrm{~cm}$ thick, but in large graywacke beds it can be as thick as 1 to $2 \mathrm{~m}$. Thin $(10$ to $30 \mathrm{~cm})$ limestone layers are present but rare. (Maps D-F) 
Kodiak Formation (Late Cretaceous) — The Kodiak Formation is an approximately 5,000-m-thick sequence of argillite and graywacke turbidites that have been structurally repeated many times by thrust faults (Nilsen and Moore, 1979; Sample and Moore, 1987). It ranges from 5- to 10-m-thick massive graywacke beds to 5 - to 10 -cm-thick rhythmically bedded argillite. Argillite-rich sections are almost black, whereas the graywacke is dark gray. Graded beds and Bouma sequences are present throughout the unit. In argillite-rich sections, bedding is sharply defined, and strike is quite consistent. Also, larger scale folds on the order of tens to hundreds of meters with well-developed axial planar cleavage are present. Thrust-fault-dominated shear zones separate kilometer-scale packages of coherent strata. The Kodiak Formation has an early Maastrichtian age that is based on the presence of Inoceramus kusiroensis and Inoceramus balticus molluscan fossils (Jones and Clark, 1973; Sample and Reid, 2003). (Maps A-F)

Hornfels-Hornfelsic argillite and graywacke in which bedding has been significantly thinned and, in some cases, entirely pulled apart so that graywacke beds exist only as isolated lozenges and rods. Metamorphic cordierite and biotite are present. The unit is interpreted as Kodiak Formation that has undergone high-temperature shear in response to magmatic intrusion and movement on the Kalsin Bay Fault. Unit Kkt differs from Kodiak Formation (Kk) rocks mapped within the cordierite zone surrounding many of the Kodiak Batholith plutons by also having experienced shear related to the Kalsin Bay Fault. The Kkt outcrop on the southwest side of Sitkalidak Island (map D) is exposed along strike with the Sitkalidak pluton (map E) and indicates its underground southwestern extension. (Maps D, E)

Kkl Leucocratic dikes-Highly disrupted Kodiak Formation intruded by leucocratic dikes. Bedding has been sheared and is much less coherent than elsewhere in the Kodiak Formation. This unit is located between the gabbro and granite bodies on Sitkalidak Island (map E). Dikes shown only in map E cross section. (Maps D, E)

\section{IGNEOUS ROCKS}

Kodiak batholith (Paleocene) - The Kodiak batholith is an elongate body of biotite granite, granodiorite, and tonalite that runs along the mountainous axis of Kodiak Island. It includes the greater than $700 \mathrm{~km}^{2}$ elongate body and several compositionally similar satellite plutons that surround it (fig. 1). The Kodiak batholith is an informal unit that has been further subdivided into units based on the amount of partially assimilated host-rock inclusions. It ranges in age from $59.2 \pm 0.2 \mathrm{Ma}$ at the southwest end to $58.4 \pm 0.2 \mathrm{Ma}$ at its northeast tip (table 1; fig. 1; Farris and others, 2003, 2006)

Ta Aplite dikes-White to tan, fine-grained quartz and potassium feldspar aplite dikes, $1 \mathrm{~cm}$ to $10 \mathrm{~m}$ wide, that intrude into the high-assimilation unit of the Kodiak batholith. (Map A)

Tgl Low-inclusion unit-Medium-grained $(0.5$ to $1 \mathrm{~cm})$ biotite granite and granodiorite containing quartz, potassium feldspar, plagioclase, biotite, and ilmenite. The rocks are composed of 5 to 10 percent mafic minerals (biotite and ilmenite only) and have a low percentage of host-rock inclusions. Unlike in the medium- and high-inclusion units, sillimanite xenocrysts are very rare or absent. Near the pluton margin, muscovite and relatively unaltered host-rock blocks are present, and the percentage of biotite and ilmenite decreases. At the northeast tip of the batholith (near Terror Lake, map A), granite predominates and the unit is homogeneous. However, toward the southwest end of the batholith (map D), the low-inclusion unit is less siliceous. Point counts by Hill and others (1981) from Three Saints Bay indicate that the lowinclusion unit is a biotite tonalite there. Those rocks are included in this unit owing to a low percentage of xenocrysts and xenoliths that are characteristic of the medium- and high-inclusion units. (Maps A-D)

Tgm Medium-inclusion unit - Biotite granodiorite and tonalite containing as much as 5 to 10 percent partially assimilated host-rock material composed of 1 - to $15-\mathrm{cm}$ pure quartz clots, 1- to 30 -cm biotite aggregates, 1- to 10 -cm sillimanite xenocrysts, and 5- to 50-cm metamorphosed host-rock xenoliths. The xenoliths have been segregated into alternating layers of biotite and quartz and feldspar. The quartz clots and biotite aggregates are interpreted to be xenoliths that have been split apart. Andalusite, kyanite, and garnet xenocrysts are also present, but they are less common than sillimanite. These rocks are composed of 10 to 20 percent biotite. Sillimanite xenocrysts are common in the medium- and high-inclusion units, but they are not common in the low-inclusion unit. (Maps A, D)

Tgh High-inclusion unit - Biotite granodiorite and tonalite containing 10 to 50 percent partially assimilated host-rock material consisting of 1 - to $15-\mathrm{cm}$ pure quartz clots, 1 - to $30-\mathrm{cm}$ biotite aggregates, 1 - to $10-\mathrm{cm}$ sillimanite xenocrysts, and 5- to 50-cm altered host-rock xenoliths. The xenoliths have been segregated into alternating layers of biotite and quartz and feldspar. Andalusite, kyanite, and garnet are also present but to a lesser degree. These rocks are composed of 20 to 40 percent biotite and appear as a mixture of highly metamorphosed host-rock fragments and biotite-rich granite. The high percentage of biotite tends to increase the observed intensity of the magmatic fabric. (Map A) 
Tglc Leucocratic muscovite-bearing granite-Leucocratic muscovite-bearing, biotite-poor granite. Garnet has also been reported in this unit (Shew and Wilson, 1981), but it is not common. Muscovite concentrations increase with proximity to host-rock blocks. Biotite is found primarily in schlieren bands, which generally parallel the blocks of host rock. Such blocks are widespread, in various stages of disaggregation, and typically are fragmented along bedding planes. Quartz-filled miarolitic cavities are also present. (Map C)

Trenchward belt (Paleocene) - The trenchward belt is an informal group of units of Paleocene igneous rocks along and to the south of the Kalsin Bay Fault on Kodiak Island. It is composed of small granitic and gabbroic plutons, dikes of porphyritic gabbro, basalt, and andesite, and pillow basalt. Most of these rocks intruded the Ghost Rocks Formation and range in age from 60 to $63 \mathrm{Ma}$ (table 1; fig. 1; Moore and others, 1983); however, some are interbedded with the Ghost Rocks Formation strata (Plumley and others, 1983; Moore and others, 1983)

Tpg Biotite-rich granodiorite - Biotite-rich, clinopyroxene-bearing granodiorite and tonalite. Clinopyroxene phenocrysts have been partially resorbed and altered to biotite. The percentage of mafic minerals ranges from 1 to 25 percent and these minerals show considerable heterogeneity down to the scale of an individual outcrop. Clinopyroxene increases in abundance with proximity to gabbroic pods, which can be as much as hundreds of meters in diameter. Larger $(1-5 \mathrm{~mm})$ phenocrysts of plagioclase are commonly surrounded by a matrix of granular, intergrown quartz and alkali feldspar. (Maps E, F)

Tpgs Granodiorite and granite with voluminous stoped blocks - Granodiorite and granite that contain greater than 25 percent stoped blocks by volume. Petrographically, the unit is similar to unit Tpg, except it contains a higher percentage of quartz and feldspar. At the outcrop scale, host-rock blocks have dark reaction rims and can be visually reassembled like puzzle pieces. The blocks are fragments of the Ghost Rocks Formation and range in diameter from less than $1 \mathrm{~cm}$ to greater than $5 \mathrm{~m}$. Some have sharp discordant margins, whereas others are gradational. Larger fragments tend to be light-gray, fine-grained, and homogeneous graywacke, whereas some of the smaller ones have white rectangular feldspar in their interiors. Where host-rock block concentrations are highest, the granite is most leucocratic and composed almost entirely of quartz, potassium feldspar, and host-rock remnants. Garnet and aluminosilicate xenocrysts observed in the medium- and high-inclusion units of the Kodiak batholith are not present. (Map F)

Tcg Porphyritic gabbro-Porphyritic clinopyroxene-plagioclase gabbro. Plagioclase phenocrysts, 1 to 2 cm in diameter, form a framework that is filled with smaller, intergrown clinopyroxene and plagioclase grains. Commonly intruded into the Ghost Rocks Formation as thick 10- to 50-m-wide dikes that fine upward. The upper sections of the dikes are almost entirely devoid of large plagioclase crystals and, in some places, grade into basalt. Several dikes on the northwest side of Pasagshak Bay are topped by basaltic balloon-like structures with narrow necks that have been injected into the overlying host rock. In the Pasagshak pluton (map F) and on Sitkalidak Island (map E), the gabbro is more equigranular and coarser grained. (Map F)

Tdp Fine-grained basalt - Very fine grained basalt to andesite dikes and pillows that are typically altered to greenstone. In hand sample, individual crystals are difficult to observe, but altered clinopyroxene phenocrysts are present. The groundmass is composed of plagioclase microlites, but this is not observable in the field. The basalt is intruded as $20-\mathrm{cm}$ - to $20-\mathrm{m}$-wide dikes. Also present are rectangular stacks of pillow basalt and andesite. The dikes crosscut mélange features in the Ghost Rocks Formation and sometimes grade into pillows. However, some bedding planes do wrap conformably around the top of pillow-basalt piles. The intrusions have chilled margins, and the surrounding host rock has been baked. Fragments of the Ghost Rocks Formations have been entrained in the basalt. Crosscutting calcite veins are common. The surface of certain individual pillows is covered with polygonal and rectangular darker colored basalt fragments that are likely hyaloclastite fragments. In the Pasagshak Bay area (map F), ${ }^{40} \mathrm{Ar} /{ }^{39} \mathrm{Ar}$ dating on a 3-m-wide dike yielded an age of 60.15 $\pm 0.86 \mathrm{Ma}$ (Farris, 2010). (Map E, F)

\section{References Cited}

Allison, R.C., 1976, Late Oligocene through Pleistocene molluscan faunas in the Gulf of Alaska region: International Congress on Pacific Neogene Stratigraphy, 1st, Tokyo 1976, Abstract, p. 10-13.
Ayuso, R.A., Haeussler, P.J., Bradley, D.C., Farris, D.W., Foley, N.K., and Wandless, G.A., 2009, The role of ridge subduction in determining the geochemistry and $\mathrm{Nd}-\mathrm{Sr}-\mathrm{Pb}$ isotopic evolution of the Kodiak batholith in southern Alaska: Tectonophysics, v. 464, p. 137-163.

Barker, Fred, Farmer, G.L., Ayuso, R.A., Plafker, George, and Lull, J.S., 1992, The 50 Ma granodiorite of the eastern Gulf 
of Alaska-Melting in an accretionary prism in the forearc: Journal of Geophysical Research, v. 97, p. 6757-6778.

Bradley, D.C., Haeussler, P.J., and Kusky, T.M., 1993, Timing of early tertiary ridge subduction in southern Alaska: U.S. Geological Survey Bulletin 2068, p.163-177.

Bradley, D.C, Kusky, T., Haeussler, P.J., Goldfarb, Richard, Miller, M.L., Dumoulin, J., Nelson, S.W., and Karl, S., 2003, Geologic signature of early Tertiary ridge subduction in Alaska, in Sisson V.B., Roeske, S.M., and Pavlis, T.L., eds., Geology of a transpressional orogen developed during ridgetrench interaction along the North Pacific margin: Geological Society of America Special Paper 371, p. 19-50.

Bradley, D.C., Parrish, Randall, Clendenen, William, Lux, Daniel, Layer, P.W., Heizler, Mathew, and Donley, D.T., 1998, New geochronologic evidence for the timing of early Tertiary ridge subduction in southern Alaska: U.S. Geological Survey Professional Paper 1615, p. 5-21.

Capps, S.R., 1937, Kodiak and adjacent islands, Alaska: U.S. Geological Survey Bulletin 880-C, plate 2.

Carden, J.R., Connelly, W., Forbes, R.B., and Turner, D.L., 1977, Blueschists of the Kodiak Islands, Alaska - an extension of the Seldovia schist terrane: Geology, v. 5, p. 529-533.

Clendenen, W.S, Fisher, D., and Byrne, T., 2003, Cooling and exhumation of the Kodiak accretionary prism, southwest Alaska, in Sisson, V.B., Roeske, S.M., and Pavlis, T.L., eds., Geology of a transpressional orogen developed during ridgetrench interaction along the North Pacific margin: Geological Society of America Special Paper 371, p. 71-88.

Farris, D.W., 2010, Tectonic and petrologic evolution of the Kodiak batholith and the trenchward belt, Kodiak Island, AK-Contact Fault juxtaposition?: Journal of Geophysical Research, v. 115, no. B7, 29 p., https://doi.org/10.1029/2009JB006434.

Farris, D.W., Haeussler, P., Friedman, R., Paterson, S.R., Saltus, R.W., and Ayuso, R., 2006, Emplacement of the Kodiak batholith-A consequence of slab-window migration: Geological Society of America Bulletin, v. 118, no. 11-12, p. 1360-1376.

Farris, D.W., Haeussler, P.J., Paterson, S.R., and Friedman, Richard, 2003, Slab-window segmentation and the evolution of the Sanak-Baranof belt-An example from Kodiak Island, AK [abs.]: Geological Society of America Abstracts with Programs, v. 35, no. 6, p. 428.

Farris, D.W., Haeussler, P.J., and Ullrich, Thomas, 2005, The Kodiak batholith and the trenchward Ghost Rocks Formation magmatic belt, Kodiak Island, Ak-Tectonic juxtaposition or two discrete events? [abs.]: Geological Society of America Abstracts with Programs, v. 37, no. 7, p. 80.

Fisher, Donald, and Byrne, Timothy, 1987, Structural evolution of underthrusted sediments, Kodiak Islands, Alaska: Tectonics, v. 6, no. 6, p. 775-793.

Garver, J.I., and Davidson, C.M., 2015, Southwestern Laurentian zircons in Upper Cretaceous flysch of the ChugachPrince William terrrane in Alaska: American Journal of Science, v. 315, no. 6, p. 537-556.

Haeussler, P.J., Bradley, D.C., Goldfarb, R.J., Snee, L.W., and Taylor, C.D., 1995, Link between ridge subduction and gold mineralization in southern Alaska: Geology, v. 23, no. 11, p. 995-998.
Haeussler, P.J., Bradley, D.C., Wells, R.E., and Miller, M.L., 2003, Life and death of the Resurrection plate-Evidence for its existence and subduction in the northeastern Pacific in the Paleocene-Eocene time: Geological Society of America Bulletin, v. 115 , no. 7, p. 867-880.

Harris, N.R., Sisson, V.B., Wright, J.E., and Pavlis, T.L., 1996, Evidence of Eocene mafic underplating during forearc intrusive activity, eastern Chugach Mountains, Alaska: Geology, v. 24, p. 263-266.

Hill, Malcom, Morris, Julie, and Whelan, Joseph, 1981, Hybrid granodiorites intruding the accretionary prism, Kodiak, Shumagin and Sanak Islands, southwest Alaska: Journal of Geophysical Research., v. 86, no. B11, p. 10569-10590.

Hudson, T.L., 1994, Crustal melting events in Alaska, in Plafker, G., and Berg, H.C., eds., The geology of AlaskaThe geology of North America, v. G-1: Boulder, Colo., Geological Society of America, p. 657-671.

Jones, D.L., and Clark, S.H.B., 1973, Upper Cretaceous (Maastrichtian) fossils from the Kenai-Chugach Mountains, Kodiak and Shumagin Islands, southern Alaska: U.S. Geological Survey Journal of Research, v. 1, p. 1419-1427.

Kusky, T.M., Bradley, Dwight, Donley, D.T., Rowley, David, and Haeussler, P.J., 2003, Controls on intrusion of near-trench magmas of the Sanak-Baranof belt, during Paleogene ridge subduction, and consequences for forearc evolution, in Sisson V.B., Roeske, S.M., and Pavlis, T.L., eds., Geology of a transpressional orogen developed during ridge-trench interaction along the North Pacific margin: Geological Society of America Special Paper 371, p. 269-292.

Mahjoor, A.S., 2011, Detrital zircon dating of the Kodiak accretionary complex, south Alaska: Florida State University, Masters thesis, $76 \mathrm{p}$.

Marshak, R.S., and Karig, D.E., 1977, Triple junctions as a cause for anomalously near-trench igneous activity between the trench and volcanic arc: Geology, v. 5, no. 4, p. 233-236.

Marvin, R.F., and Dobson, S.W., 1979, Radiometric ages; compilation B: Isochron/West, no. 26, p. 3-30.

Meneghini, F., Di Toro, G., Rowe, C.D., Moore, J.C., Tsutsumi, A., and Yamaguchi, A., 2010, Record of mega-earthquakes in subduction thrusts; the black fault rocks of Pasagshak Point (Kodiak Island, Alaska): Geological Society of America Bulletin, v. 122, no. 7-8, p. 1280-1297.

Moore, J.C., Byne, Timothy, Plumley, P.W., Reid, Mary, Gibbons, Helen, and Coe, R.S., 1983, Paleogene evoloution of the Kodiak Islands, Alaska-Consequences of ridge-trench interaction in a more southerly latitude: Tectonics, v. 2, no. 3, p. 265 .

Moore, G.W., 1967, Preliminary geologic map of Kodiak Island and vicinity, Alaska: U.S. Geological Survey, Open-File Report 67-161, scale 1:250000.

Nilsen, T.H., and Moore, G.W., 1979, Reconnaissance study of Upper Cretaceous to Miocene stratigraphic units and sedimentary facies, Kodiak and adjacent islands, Alaska: U.S. Geological Survey Professional Paper 1093, 34 p.

Plafker, George, Moore, J.C., and Winkler, G.R., 1994, Geology of the Southern Alaska margin, in Plafker, G., and Berg, H.C., eds., The geology of Alaska-The geology of North America, v. G-1: Boulder, Colo., Geological Society of America, p. 389-449. 
Plafker, George, Nokleberg, W.J., and Lull, J.S., 1989, Bedrock geology and tectonic evolution of the Wrangellia, Peninsular, and Chugach terranes along the Trans-Alaska Crustal Transect in the Chugach Mountains and southern Copper River basin, Alaska: Journal of Geophysical Research, v. 94, no. B4, p. 4255-4295.

Plumley, P.W., Coe, R.S., and Byrne, Timothy, 1983, Paleomagnetism of the Paleocene Ghost Rocks Formation, Prince William terrane, Alaska: Tectonics, v. 2, p. 295-314.

Rioux, M., Mattinson, J., Hacker, B., Keleman, P., Blusztajn, J., Hanghoj, K., and Gehrels, G., 2010, Intermediate to felsic middle crust in the accreted Talkeetna arc, the Alaska Peninsula and Kodiak Island, Alaska-An analogue for lowvelocity middle crust in modern arcs: Tectonics, v. 29, 17 p., https://doi.org/10.1029/2009TC002541.

Roeske, S.M., Mattinson, J.M., and Armstrong, R.L., 1989, Isotopic ages of glaucophane schists on the Kodiak Islands, southern Alaska, and their implications for the Mesozoic tectonic history of the Border Ranges fault system: Geological Society of America Bulletin, v. 101, p. 1021-1037.

Rowe, C.D., Moore, J.C., Meneghini, F., and McKeirnan, A.W., 2005, Large-scale pseudotachylytes and fluidized cataclasites from an ancient subduction thrust fault: Geology, v. 33, no. 12, p. 937-940.

Sample, J.C., and Moore, J.C., 1987, Structural style and kinematics of an underplated slate belt, Kodiak and adjacent islands, Alaska: Geological Society of America Bulletin, v. 99, no. 1, p. 7-20.

Sample, J.C., and Reid, M.R., 2003, Large-scale, latest Cretaceous uplift along the northeast Pacific Rim-Evidence from sediment volume, sandstone petrography, and $\mathrm{Nd}$ isotope signatures of the Kodiak Formation, Kodiak Islands, Alaska, in Sisson V.B., Roeske, S.M., and Pavlis, T.L., eds., Geology of a transpressional orogen developed during ridge-trench interaction along the North Pacific margin: Geological Society of America Special Paper 371, p. 51-70.

Shew, Nora, and Wilson, F.H., 1981, Map and table showing radiometric ages of rocks in southwestern Alaska: U.S. Geological Survey Open-File Report 81-886, 27 p.

Sisson, V.B., Poole, P.R., Harris, N.R., Burner, H.C., Pavlis, T.L., Copeland, P., Donelick, R.A., and McLelland, W.C., 2003, Geochemical and geochronologic constraints for the genesis of a tonalite-trondhjemite suite and associated mafic intrusive rocks in the eastern Chugach Mountains, Alaska-A record of ridge-transform subduction, in Sisson V.B., Roeske, S.M., and Pavlis, T.L., eds., Geology of a transpressional orogen developed during ridge-trench interaction along the North Pacific margin: Geological Society of America Special Paper 371, p. 293-326.

Tangalos, G.E., Farris, D.W., Valley, John, Haeussler, Peter, and Haileab, Bereket, 2003, Genesis and contamination of the Kodiak batholith, Kodiak Island, Alaska-Using $\delta^{18} \mathrm{O}$ to quantify the assimilated component of the batholith [abs.]: Geological Society of America Abstracts with Programs, v. 35 , no. 6, p. 325 .

Wilson, F.H., 1981, Map and table showing radiometric ages of rocks in the Aleutian Islands and Alaska Peninsula: U.S. Geological Survey Open-File Report 81-471, 23 p. 


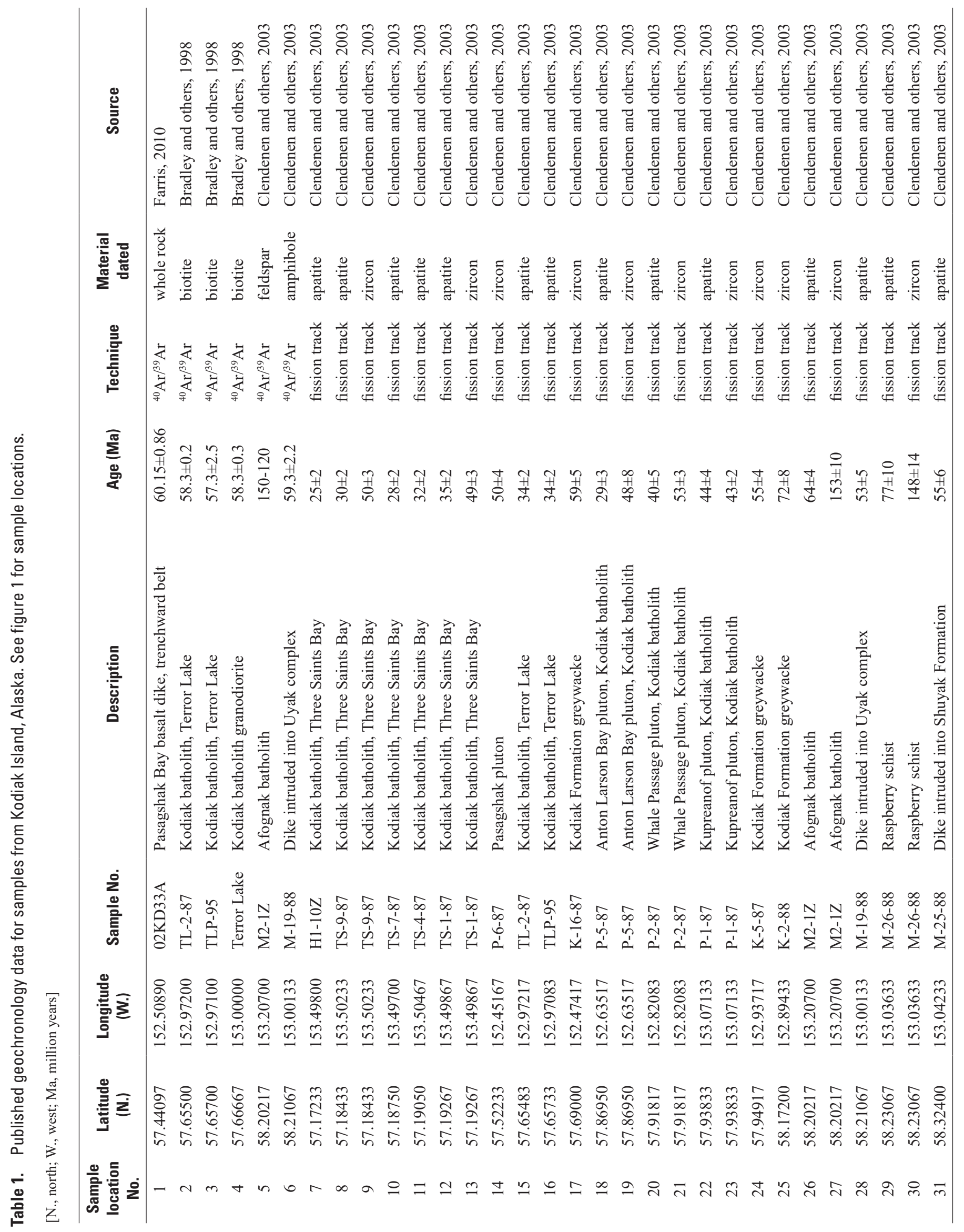




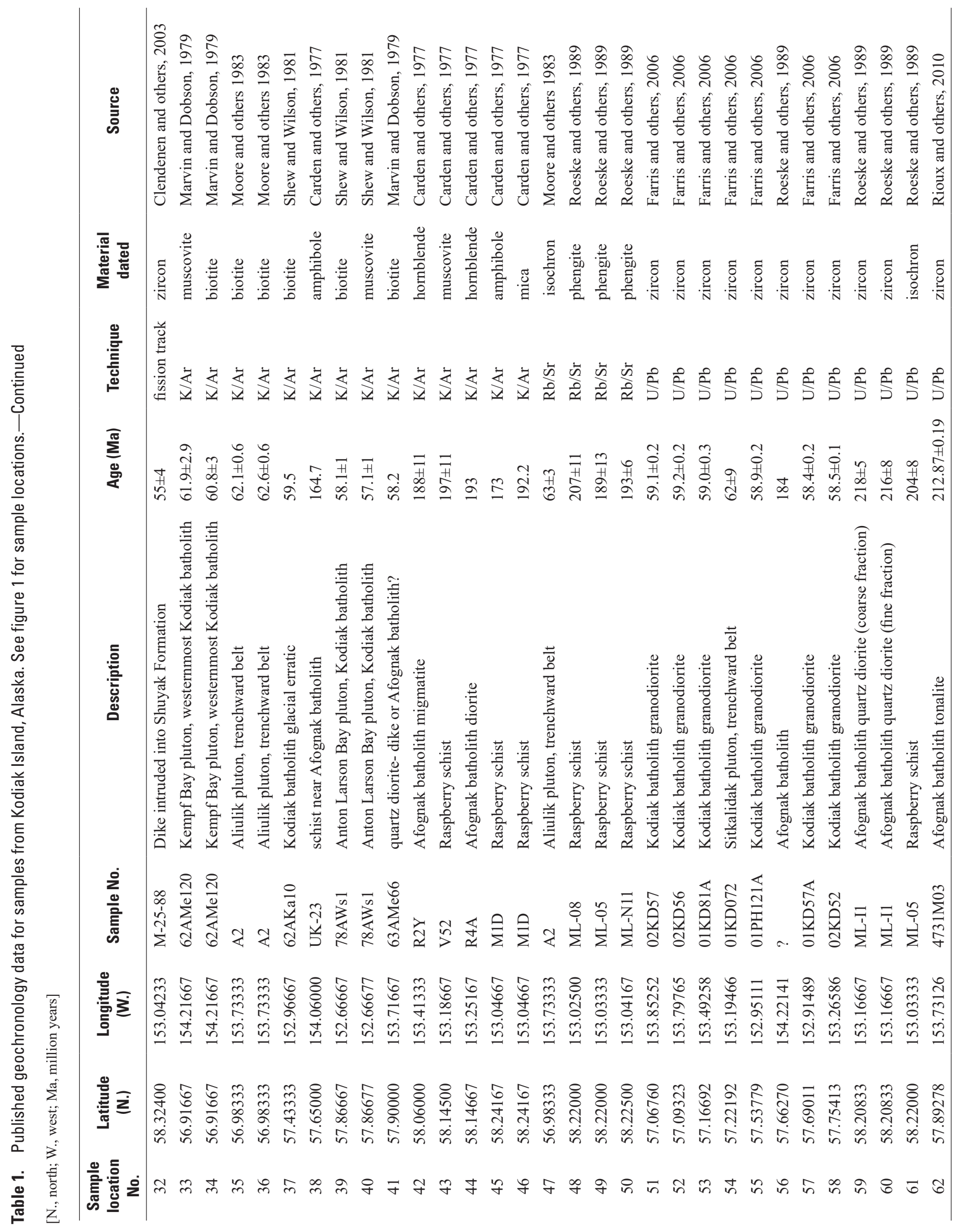

